\title{
Taxes and Leverage at Multinational Corporations
}

\author{
By \\ Michael Faulkender ${ }^{\mathrm{a}}$ and Jason Smith ${ }^{\mathrm{b}}$
}

\begin{abstract}
:
Empirical research has struggled to document the variation in recent corporate capital structures as arising from variation in estimated corporate income tax rates. We argue that in previous studies, both the tax rates being applied to multinational corporations and the taxable income earned has been miss-measured, a result of firms operating in many foreign countries. Using a sample of multinational firms collected in the Bureau of Economic Analysis' annual survey combined with each firm's respective income and country specific tax rate, we revisit this taxleverage puzzle. Empirically we find that firms do have higher leverage ratios and lower interest coverage ratios when they operate in countries with higher tax rates, as theory would suggest. Our results demonstrate that the primary benefit of leverage under the trade-off theory of capital structure continues to have empirical support.
\end{abstract}

Note: The statistical analysis of firm-level data on U.S. multinational companies was conducted at the Bureau of Economic Analysis, U.S. Department of Commerce, under arrangements that maintain legal confidentiality requirements. The views expressed in the paper are those of the authors and do not reflect official positions of the U.S. Department of Commerce.

The authors would like to thank Vojislav Maksimovic, Mitchell Petersen, and William Zeile for helpful comments as well as seminar participants at the University of Michigan, University of Montana, and Utah State University. All errors are our own.

${ }^{a}$ Robert H. Smith School of Business, University of Maryland, College Park, MD 20742. Email: mfaulken@rhsmith.umd.edu. Phone: 301-405-1064

${ }^{\mathrm{b}}$ Huntsman School of Business, Utah State University, Logan, UT 84322. Email: jason.smith@usu.edu. Phone: 435-797-2363 


\section{Introduction}

The trade-off theory of capital structure postulates that firms trade-off the benefits of raising external capital from debt holders against the costs of having such fixed obligations. The primary benefit of issuing debt is hypothesized to arise from the fact that interest paid to debtholders is deducted before corporate income taxes are calculated whereas payments to equity holders do not receive a tax deduction. The reduction in taxes is considered a wealth transfer to investors from the government arising entirely from the capital structure choice of the firm. For a debt issuance that is anticipated to be perpetually rolled over, the value of that wealth transfer is approximately the amount of the debt issuance multiplied by the corporate income tax rate. For a country like the United States with a relatively high corporate income tax rate (a statutory federal rate of 35\%), theory argues that firms in this country should have significant leverage. Yet when finance researchers attempt to empirically estimate the size of this benefit and whether variation in corporate capital structures is explained by variation in the tax status of corporations, the results have been less conclusive than theory would predict.

We argue that one reason empirical researchers may have failed to find significant effects is because consolidated financial statements that are publicly disclosed make it difficult to ascertain how much of the income is earned in which tax jurisdiction. Previous research has implicitly assumed that all of the firm's income is either earned in the United States or if earned overseas, that the funds are contemporaneously repatriated to the United States (Graham (1996a) as an example among many). Either way, it generates the assumption that the US tax code is the binding tax structure when estimating the benefits of leverage. However, significant evidence has emerged that much of the observed increase in corporate liquidity over the last couple decades can be explained by the tax differential between the tax jurisdictions of US foreign affiliates and 
the US (Foley, Hartzell, Titman, and Twite (2007)). By retaining the earnings in the foreign affiliate, and thus deferring the payment of US taxes, firms have significantly decreased their tax liabilities.

For example, a United States Senate committee recently investigated the tax status of Apple, Inc. and found that it had structured its foreign operations in a way that enabled it to almost entirely eliminate its contemporaneous corporate income tax obligation (McCoy (2013)). This retention of earnings in the foreign affiliates will reduce the benefits of adding leverage to the capital structure of the firm since the effective tax rate confronting the foreign earnings of the firm will, at least contemporaneously, be significantly lower than the rate they would pay in the United States, close to zero in the case of Apple.

The objective of our study is to estimate how much such variation in tax structure arising from global operations explains the variation in capital structure that we observe among US publicly traded multinational firms. Do multinationals with significant earnings in low-tax jurisdictions rely significantly less on debt in their capital structure than otherwise equivalent firms that are mostly based in the United States? By how much does the locating of operations in low tax jurisdictions alter corporate financial structure?

Unfortunately, data restrictions have made answering this question difficult because firms' required public disclosures do not offer sufficient information to identify the tax jurisdiction where profits have been generated. While foreign sales are a widely populated disclosure item in firms' $10-\mathrm{K}$ filings, the incomes of such foreign operations are not nearly as available. Additionally, the disclosed location is often so generic that it does not allow a specific identification of the tax jurisdiction (e.g. a disclosure of a European operation does not indicate 
how much revenue is generated in which specific European country). The Bureau of Economic Analysis (BEA) conducts a mandatory survey of U.S. multinational companies that generates the data that is needed to address these data shortcomings. ${ }^{1}$ Cleaner data on the income and location of multinational affiliates enables significantly more reliable estimates of the true tax rates such firms confront and thereby provides for much stronger tests of the tax benefits of debt in explaining the observed variation in firm capital structures. We employ the BEA's multinational firm data and augment it with international tax data which contains both statutory rates as well as progressive tax schedules where applicable.

Since theory argues that financial decisions are driven by marginal rates, having tax rate estimates that are closer to the true marginal rates that firms contemporaneously confront, accounting for their international operations, increases the precision of our work. Using our calculated weighted average tax rate, we include otherwise identified explanatory variables for capital structure and estimate in a multivariate regression setting how much our blended tax rate measure improves our understanding of why capital structure varies across firms and, to a lesser extent, across time.

Consistent with the trade-off theory, variation in corporate tax rates significantly explains observed variation in the capital structure of multinationals. Over the time period for which we have data on multinational operations and tax rates, we find that firms that realize most of their income in low tax jurisdictions have corporate leverage ratios that are significantly lower, and interest coverage ratios that are significantly higher, than otherwise similar firms whose earnings are primarily derived in high corporate income tax jurisdictions. These results are robust to

\footnotetext{
${ }^{1}$ The company-level data from this survey, which by law are confidential, are collected for the purpose of producing publically available aggregate statistics on the operations of multinational companies.
} 
incorporating cash into our leverage measures. The results of this paper indicate that taxes do indeed have a first order effect on corporate leverage decisions.

Before proceeding, it is important to address the issue of endogeneity. Our results document a correlation between high marginal tax rates and significantly greater use of leverage. If the tax status of the firm were exogenous, our results would appropriately be interpreted as the variation in tax structure causing firms to vary their capital structure, as theorized. However, tax structure arising from the locations of firm operations is endogenous; firms choose where to locate their operations. It is therefore equivalently appropriate to interpret the results as consistent with firms which have significant financial distress costs altering the location of their operations to shield their income from taxation. In other words, firms with low financial distress costs may be less sensitive to the particular location of their operations (making such firms tax rates higher on average) because they shield their income with interest expense arising from debt. Those with high distress costs are more selective in where they operate (lower corporate tax rates on average) because it is significantly more costly to use debt to shield their income from taxation than to alter the location of their operations. This interpretation is still consistent with debt as an instrument (potentially among many) to create firm value by reducing its corporate income taxes; whether firms use it depends upon the cost of locating its operations in particular tax jurisdictions relative to the financial distress costs of using debt.

The remainder of this paper is structured as follows. Section II contains a brief review of the relevant literature on capital structure and international operations. Section III explains the empirical methodology and data used to estimate whether variation in foreign operations affects how firms structure their external capital. Section IV describes our results. Finally, Section V concludes. 


\section{Literature Review}

Capital structure research is focused broadly on two traditional views: the trade-off theory where a firm balances the costs and benefits of debt to yield an optimal leverage ratio and the pecking order theory of Myers (1984) which minimizes the adverse selection costs associated with security issuance. Graham and Leary (2011) provide a thorough review of the capital structure literature. Much empirical work on the trade-off theory has focused on explaining debt levels and adjustment toward a target leverage ratio (e.g. Leary and Roberts (2005), Flannery and Rangan (2006), Lemmon, Roberts, and Zender (2008), and Frank and Goyal (2009)). Although there appears to be consensus (Welch (2004) being a notable exception) that firms do have a leverage target, adjustment toward that target appears to be very slow. Faulkender, Flannery, Hankins, and Smith (2012) show that for firm-years with low adjustment costs, because their earnings or investments already require accessing the capital markets, firms will move relatively quickly toward target leverage.

One of the theoretical first order explanations for variation in leverage arises from the differential treatment of debt and equity for corporate tax purposes. As the corporate tax rate increases, using debt to eliminate the corporate income tax that would otherwise be paid on the proceeds of the firms operations becomes more valuable. One of the challenges for researchers is that within a country in a particular year, the corporate tax rate is the same for all firms, hence minimal cross-sectional variation. There is still some variation in expected tax rates due to tax loss carry-forwards arising from operating losses potentially delaying tax benefits from leverage. Graham (1996a) estimates such rates and finds evidence of higher marginal tax rate firms using more debt, but it doesn’t appear to be a first order concern. Graham (1996b) further demonstrates that simulated tax rates are the best proxy for the "true" marginal tax rate. Blouin, Core, and 
Guay (2010) similarly estimate tax rates making different assumptions about earnings growth and therefore what marginal tax rates firms are confronting. They find that their tax rate measures better explain variation in leverage changes than the estimates of Graham (1996a), particularly for firms who only operate in the US.

However, the literature still struggles to explain the levels of observed leverage as a function of what theory suggests should be a first-order factor: the tax differential of debt versus equity. Based on the existing literature, a puzzle still exists as to why firms consistently carry lower than anticipated levels of debt given the significant benefits that theoretically arise from using debt to shield income from corporate taxes.

Faulkender and Petersen (2012), among others, discuss the tax considerations firms make when determining whether to keep earnings in their foreign subsidiaries versus repatriating them immediately. Essentially, the US tax code treats symmetrically the earnings of domestic and foreign operations when the foreign earnings are repatriated in the same year that they are earned. The US tax code grosses up the amount of the earnings repatriated to the domestic parent by the foreign tax rate to arrive at the original operating earnings value and then applies the US tax rate less a credit for taxes paid by the foreign affiliate on those earnings. As Faulkender and Petersen (2012) explain, taxes are the same in those cases. However, because the US tax liability arises when the earnings are repatriated, not when they are earned, a significant deferral benefit is realized when those earnings are left in the foreign subsidiary. For a firm that anticipates permanently retaining those earnings in its foreign subsidiary, the US tax code is irrelevant; it is the foreign tax rate that is binding on those earnings. 
We test whether firms with significant foreign operations in low tax jurisdictions (and whose effective marginal tax rate has been overestimated by previous work) carry significantly less total corporate debt than firms that primarily operate in high tax jurisdictions. Such a finding would demonstrate the first order nature of corporate taxes in the capital structure decisions of firms, contrary to most of the existing literature. Foley, Hartzell, Titman, and Twite (2007) find that firms will increase or decrease cash holdings in foreign affiliates, and thus their overall cash level, depending on the tax burden from repatriating foreign income. This paper uses similar data to explain firm debt levels after accounting for the relevant tax implications of foreign earnings.

Several papers have made use of firm-level data on U.S. multinational companies within the Bureau of Economic Analysis. The closest paper to ours is Desai, Foley, and Hines (2004), which find that the local tax rate does affect the capital structure of the affiliates. We are interested in the total debt of the firm and are less focused on whether high tax jurisdiction affiliates are lending to low tax jurisdiction affiliates, the effects of which would cancel out when aggregated. Antras, Desai, and Foley (2009) use the direct or indirect ownership or control by a single U.S. legal entity as a direct investment to analyze costly financial contracting and weak investor protection influence across borders. Desai, Foley, and Forbes (2008) use multinational firm data to analyze how financial constraints and product market exposures determine the response to sharp depreciations. Desai, Foley, and Hines (2011) analyze the extent to which tax deferral and other policies inefficiently subsidize U.S. direct investment abroad.

A large literature also exists that recognizes alternative ways for firms to shield income from corporate income taxes. Graham and Tucker (2006) examine leases, transfer pricing, crossborder dividend capture amongst others and document that during the sample tax shelters amounted to 9\% of asset value. Graham et al. (2004) show that debt policy at Standard \& Poors 
100 and Nasdaq 100 firms is better explained if taxable income is adjusted for deductible employee stock option exercise. Desai (2003) argues that new "enhanced opportunities for avoiding and evading taxes through cheaper, more sophisticated, and less transparent mechanisms." Other tax shelter investigations include Clausing (2003), Bartelsman and Beetsma (2003), and Hines (1997). This literature informs our understanding of how firms shelter income from taxation and the purpose of this paper is to relate those sheltering activities to the amount of total debt the firm adopts.

We expect that our tax rate estimates will be substantially different than those estimated when assuming that all operating income is contemporaneously repatriated. If highly profitable firms are the ones most likely to locate operations in low tax jurisdiction countries (they would realize the greatest benefits from incurring the costs of locating operations overseas), assuming that the US tax code is binding for them will generate significantly higher estimated tax rates under the Graham (1996a) and Blouin, Core, and Guay (2010) approaches. These are the firmyears for which we would potentially find rather low tax rates using international data. If the benefits of moving operations overseas decline as marginal tax rates decline, then the Graham (1996a) and Blouin, Core, and Guay (2010) methods will be more accurate. This type of selection bias in the decision to have significant operations in foreign affiliates will generate a zero if not negative correlation between our rates and those used in these previous studies (in fact the correlation between our estimated rates and Graham (1996a) and Blouin, Core, and Guay (2010) are 0.050 and 0.102 respectively). 


\section{Empirical Methodology and Data}

Our objective is to better understand the variation in leverage ratios observed in the data. Recent work (e.g. Lemmon, Roberts, and Zender (2008)) points to a significant firm-specific, time-invariant component that explains leverage that is currently absent from standard empirical specifications. Recognize that such a characteristic could be a factor not yet identified by the literature or alternatively, an already determined factor that is persistently misestimated. In this study, we argue that the locations and tax implications of firms' international operations are a persistent, firm-specific characteristic that theory has identified as a factor that could explain leverage, but that previous examinations have not precisely measured. ${ }^{2}$ The Bureau of Economic Analysis (BEA) conducts an annual survey that US multinationals are required by law to complete that contains numerous balance sheet and income statement items for each foreign affiliate of a US-based multinational firm. We use the BEA multinational affiliate data to better measure the variation in the tax differential between debt and equity. Does this measure significantly improve our ability to explain the observed variation in leverage ratios, in particular the firm-specific, time-invariant component?

We specifically employ two BEA U.S. multinational company surveys: the BE-10 benchmark survey and the BE-11 annual survey that contain the profitability of the various foreign affiliates of multinational firms. Because we are interested in the effects of multinational variation in taxes on leverage, our firm observations are limited to those multinationals who participate in the BEA surveys - we do not have any purely domestic firm-years in our panel. This data is available from 1994 to 2009. These locations and amounts create the weights that

\footnotetext{
${ }^{2}$ Because the location of firm earnings is highly autocorrelated, we expect that the effect will be persistent for a given firm and that the effect will be largely cross-sectional.
} 
we use in generating our weighted average tax rate variable as well as inform us of the tax rate to use for that affiliate. Tax code information for foreign jurisdictions was provided by Comtax for the years 2006 to 2012. For the period 1995 to 2005, we utilize data from the KPMG Corporate and Indirect Tax Survey. Thus the overlap in the BEA data and tax data is our sample period: 1995 to 2009. The KPMG data does not cover many of the smaller countries that Comtax data covers so for those missing observations, so we searched for alternative data sources and augmented the data were possible. If we were unable to locate tax rates for foreign jurisdictions prior to 2006, we assume that the tax rates for that period in those countries are the same as they were in 2006. ${ }^{3}$ Alternatively, we could estimate the implied tax rate using the ratio of taxes paid divided by pre-tax income. The downside of such an approach is that many tax systems are progressive so the average rate (which is derived from this quotient) will tend to under-estimate the marginal rate, i.e. the rate on which financial decisions are theoretically made.

Recognize that we do assume that firms pay the tax rate associated with that foreign tax jurisdiction. According to the Senate committee report, Apple structured their Ireland operations in a way that avoided both US and Irish taxes. For all firm-years in our sample, we assume that the Irish operations of a firm were subject to the $12.5 \%$ tax rate applicable in Ireland, and the same for all other countries in the sample. Should tax structures such as that identified in the Senate report for Apple be significant over our sample period, our weighted average rate rates will over-estimate true tax rates firms are facing and cause us to under-estimate the true economic effects arising from cross-sectional variation in tax exposures.

\footnotetext{
${ }^{3}$ Note that if the error with that assumption is random, the miss-measurement would serve to underestimate our coefficient of interest.
} 
The measure that we have constructed is a weighted average tax rate using the percentage of EBIT (earnings before interest and taxes) generated in each affiliate in that fiscal year with the tax rate in the tax jurisdiction of that affiliate. So if 50\% of the total operating income in 2006 were generated in the United States, 30\% in foreign affiliate A which is located in Ireland, and the remaining $20 \%$ in affiliate B which is located in Germany, we would form the true tax rate confronting the firm in 2006 by taking the weighted average:

$$
\tau_{\text {Firm }, 2006}=50 \% \tau_{U S}+30 \% \tau_{\text {Ireland }}+20 \% \tau_{\text {Germany }}
$$

Under the assumption that the next dollar of income will be split across the three operating locations at the same percentages as an average dollar of income, this blended tax rate represents our estimate of the marginal tax rate confronting firms prior to using interest expense to shield such income from taxation.

The question naturally emerges as to the appropriate tax rate to use in each of these countries. Significant work has been done for the United States on this question and many of these examiners have made their estimates available to researchers. For instance, the estimates of Graham (1996a) are available from John Graham's web page. The estimates of Blouin, Core, and Guay (2010) are available on WRDS. However, in both cases, these estimates assume that all of the earnings were contemporaneously taxable in the United States and therefore most likely overestimate the true tax rate confronting the US operations. We instead employ the progressive marginal rate for just the US operations. For the foreign affiliates, we use progressive tax schedules (in cases where they exist) or statutory rates (for flat corporate tax rate countries) and merge them with firm-country-year level data with the BEA survey data to estimate these weighted averages. 
We calculate firm-country-year taxable income by combining all affiliates located in a particular tax jurisdiction and then use the net income within that firm-country-year adding back foreign taxes and "other expenses" (which the BEA survey classifies as minority interest). In cases where the earnings of the foreign affiliates are negative, we assign zero weight to that affiliate for that firm-year (i.e. we do not allow negative weights). Because the survey only contains foreign operations and consolidated firm data, we assume that US-generated income is equal to the firm's total net income plus US taxes plus foreign taxes plus interest paid less the total pre-tax earnings of all of the foreign operations. Recall that capital structure decisions are theoretically based on pre-income tax and pre-interest expense income which is why both of these items are added back to net income in order to arrive at our estimate of US operating income. If our estimate of US operations is negative, we again assign zero weight to the US tax rate in estimating our weighted average.

We add these estimated tax rates to an otherwise standard regression specification for leverage that incorporates variables that have been widely used in the literature (see for instance Frank and Goyal (2009), Faulkender and Petersen (2006), and Lemmon, Roberts, and Zender (2008)). For our dependent variables of interest and the rest of our control variables, we rely upon the COMPUSTAT data that is provided by Standard and Poor's based upon annual 10-K filings. We examine a variety of leverage measures. The book leverage ratio is defined as the sum of short-term and long-term debt divided by the sum of short-term debt, long-term debt, and the book value of shareholders equity. By instead dividing total debt by the value of debt plus the firm's equity market capitalization, we arrive at the market leverage ratio. Additionally, we calculate the net book leverage ratio and net market leverage ratio as above but instead use debt minus cash in the numerator. Note that this variable therefore can take on negative values should 
the firm have more cash than interest bearing debt. All of these measures are winsorized at the $1^{\text {st }}$ and $99^{\text {th }}$ percentiles. In addition, we follow Faulkender and Petersen (2006) and employ the natural log of one plus the interest coverage ratio, defined as EBITDA divided by interest expense, to get a sense of the annual cash flow obligations of the firm relative to the scale of its earnings.

Control variables include: firm size as measured by the natural logarithm of sales, profitability as measured by EBIT over book assets, asset tangibility proxied for by the ratio of PP\&E to book assets, growth opportunities as measured by the ratio of R\&D to sales, advertising to sales, and the market-to-book ratio, the depreciation to assets ratio in order to capture depreciation tax shields, and whether the firm has public debt outstanding during the fiscal year. Observations included in our regressions must have non-missing observations for all of these variables plus have our blended tax rate, Graham (1996a) tax rates available from John Graham’s website as well as tax rates on WRDS using the Blouin, Core, and Guay (2010) estimation methodology. Since our objective is to demonstrate the difference in estimates from these different tax measures across a common sample, we require data to be available for all three measures.

Theory suggests that the larger the implied tax rate confronting the firm, the more that the tax deductibility of interest (but not payments to equity holders) would incentivize firms to adopt higher leverage ratios. Therefore, our null hypothesis of no effect of the variation in tax rates on variation of leverage is hypothesized to be rejected in favor of a positive relationship between the two. Since interest coverage is higher for firms with smaller obligatory interest payments, we hypothesize a negative relationship between our weighted average tax variable and interest coverage. 
Econometrically, we employ an OLS regression without firm fixed effects despite the considerable explanatory power they have been demonstrated to provide (Lemmon, Roberts, and Zender (2008)). Variation in international operations is highly autocorrelated. Therefore the fixed effects would span much of the variation in corporate income tax rates, greatly reducing its estimated contribution and instead assign much of the explanatory power to the fixed effects. Instead, we employ year dummies and cluster the standard errors at the firm level to capture the lack of independence among the residuals for a given firm across years (Petersen, 2009).

For all specifications, we also estimate between regressions. Since the location of foreign operations is largely firm-specific and time invariant, most of the variation in our regressions should be coming from cross-sectional differences and not from time variation for a given firm. Since between regressions are estimates of the average dependent variable on the averages of the independent variables at the firm level, these specifications will focus entirely on the crosssectional variation in leverage resulting from cross-sectional variation in estimated tax rates. These specifications do not include year effects since the estimates are on averages across time so any time series effects would come from the unbalanced nature of the panel, not due to variation over time in the average costs and benefits of leverage for all firms.

The firms that we examine are larger and more profitable than the average COMPUSTAT firm, an expected result given that we only examine multinational firms in the BEA dataset. The summary statistics are located in Table 1. In the first column, we provide statistics on the firms in the COMPUSTAT dataset over the 1995 to 2009 time period for which all relevant variables are non-missing. The second column contains the subset of firm-years for which the firm does not appear in the BEA sample while the third column contains the BEA 
dataset observations. ${ }^{4}$ Comparing the means and medians of the firms that are in our analysis (column 3) and those that are not (column 2), we see that our multinational firms are larger and more profitable but most of the capital structure measures as well as many of the control variables have similar means and medians. Looking at the tax rates that are estimated by Graham (1996) and Blouin, Core, and Guay (2010), the firm-years for which BEA has information on multinational operations has higher estimated tax rates than those firms that are purely domestic. Interestingly, our estimated tax rate is, on average, higher than the tax rate estimates of the other two methods but our median tax rate is lower.

\section{Results}

This section shows that leverage ratios are significantly higher when firms have high contemporaneous international tax exposures. We present the results of regressions containing our weighted average measure and compares them to the regression results arrived at using both the Graham (1996a) estimated tax rates and the Blouin, Core, and Guay (2010) estimates. As Blouin, Core, and Guay (2010) state, they expect their tax rates to be miss-measured for firms with significant overseas operations and find that their estimates have less explanatory power when examining multinationals relative to purely domestic firms. The contribution of our paper is that we demonstrate that when we employ a blended tax rate that takes into account the variation in the tax rates and scale of multinational operations, we greatly improve our understanding of capital structure for multinationals.

\section{$\underline{\text { Leverage Ratios }}$}

\footnotetext{
${ }^{4}$ In order to protect the identities of BEA firms, all median results listed in the third column are actually calculated using the mean of the inner nine observations.
} 
Before proceeding to those results, we first provide a baseline specification of book leverage regressed on the standard set of controls used in numerous previous studies recognizing that the relationships may be different for a panel of only multinationals over this more truncated sample period (1995 to 2009). Consistent with previous studies, rated firms, those with higher asset tangibility, and those with lower earnings have higher leverage ratios. Somewhat at odds with prior studies, firms engaged in more advertising and with higher market-to-book ratios, proxies generally interpreted as capturing cross-sectional variation in financial distress costs, have higher leverage ratios. Previous examinations on data sets containing both domestic and multinational firms have generally found that growth opportunities are negatively associated with leverage whereas we estimate a positive relationship.

Moving to the effects of taxes, we begin by adding the Graham (1996a) estimated tax rates to our baseline specification in column II and the Blouin, Core, and Guay (2010) estimates in column III. In both of these specifications, a coefficient that is negative and statistically significant is estimated. This is the opposite of what theory argues. Under these two measures of marginal tax rates, the results actually suggest that it is firms with low marginal tax rates that rely more heavily upon debt. Recall that we are only examining multinationals over a different time period than those studies examined, the likely source of the differences in results.

The shortcoming of both of these measures is the implicit assumption that foreign profits are contemporaneously repatriated making the US tax code the binding tax rate structure. However, as explained above, when firms retain the earnings in their foreign affiliates, potentially in perpetuity (or in anticipation of the US eventually moving to a territorial tax system or enactment of another repatriation tax holiday), it is the contemporaneous tax rate of the tax jurisdiction in which those operations are located that is relevant. Since we are only 
examining the capital structures of multinationals, we substitute the US-based estimates of the corporate tax rate with our weighted average effective tax rate. The results of this regression are located in column IV of Table 2.

Firms with higher estimated tax rate obligations appear to shelter more of their income from taxation by employing leverage. Looking at the estimated coefficient on our weightedaverage tax measure, we see that firms with operations located in low tax jurisdictions that generate an estimated tax rate ten percent lower than an otherwise equivalent firm (25\% instead of $35 \%$ for example) have less debt equivalent to $2.7 \%$ of the book value of the firms debt plus equity. Relative to an average book leverage ratio of $30.4 \%$, this reduction in leverage is economically significant, in addition to the coefficient being statistically significant at better than one percent.

An alternative econometric specification that focuses solely on the cross-sectional variation is to employ a between regression which regresses the firm's average book leverage ratio on the firm's average independent variables across the sample period. Since firms are unlikely to be moving operations annually with minor fluctuations in tax rates, the effect is expected to primarily be cross-sectional. Thus, a between estimate is appropriate for such a setting. The results of such specifications are located in columns V to VIII of Table 2.

Similar to the OLS results, the tax variables estimated by Graham (2006) and Blouin, Core, and Guay (2010) estimate negative effects between the average book leverage ratio and the firm-specific average estimated tax rate. Contrast that with our weighted average tax rate which in column VIII takes on a significantly positive coefficient of 0.711 which is statistically significant at better than one percent. Economically, this coefficient corresponds to a $7.1 \%$ 
higher book leverage ratio for a firm with a $35 \%$ average tax rate over the sample period compared to an otherwise identical firm with a $25 \%$ average tax rate. These results demonstrate that, contrary to some of the earlier literature finding that tax effects were negligible, firms that persistently confront high tax rates have significantly more debt, both economically and statistically, than otherwise equivalent firms who persistently face lower corporate income tax rates.

The results are very similar when we instead examine market leverage. For both the Graham (1996) measure and the Blouin, Core, and Guay (2010) measure, the signs in the OLS and the between regressions (located in Table 3) are negative and the coefficients are statistically significant at better than one percent. As with book leverage, these coefficients have signs that are opposite what is predicted by theory. However, moving to our internationally weighted tax measure, the coefficient is positive. In the OLS specification, our estimate is not statistically significant but in the between regression, the estimated coefficient is significantly different from zero with better than one percent statistical significance. Recall that an OLS estimate in a panel regression explains both the cross-sectional and time-series variation in the dependent variable whereas the between regression solely measures cross-sectional variation. Since we expect that firms do not vary the location of their operations significantly over a short time period, the firmspecific variation in the tax measure is likely to be noise. Additionally, our sample period covers the tech bubble and burst as well as the financial crisis, a time period over which market valuations moved significantly even though the benefits from shielding income from taxation did not change significantly. It is therefore not surprising that when this time-series variation is removed and we focus on the difference in the cross-section (the between regressions), we find a 
statistically and economically significant effect of variation in tax rates on the market value of leverage. ${ }^{5}$

\section{Net Leverage Ratios}

The effects that we have documented so far solely examine the extent to which firms include debt in the capital structure in relation to the effective tax rate it confronts. This examination may underestimate the true effect of variation in corporate taxation on firm financial policy. Apple, Inc. announced in 2013 that due to the sizable cash it has trapped in its foreign subsidiary yet their desire to return some of the accumulated earnings to their shareholders, the parent company would be issuing debt to fund repurchases while their foreign operations continue to accumulate cash. If such activity were happening systematically, then despite the additional leverage generating minimal tax reduction, the firm is still taking on debt at the parent company level offset by cash in the foreign subsidiary. For such firms, the net debt ratio would better explain variation in leverage. We therefore re-estimate our regressions by substituting the difference between debt and cash (plus marketable securities) in the numerator of our two leverage measures. Additionally, leverage measures are naturally truncated at zero whereas net leverage measures can take negative values if cash exceeds debt. Regressions examining net leverage do not confront the issue of a truncated lower bound. The results of net book leverage regressions are located in Table 4 and net market leverage results are located in Table 5.

\footnotetext{
${ }^{5}$ Even though year fixed effects are included in the OLS specification, they will not entirely remove the variation in leverage ratios arising from volatile equity prices. Consider a firm with zero leverage versus one with an average market leverage ratio of 50\%. The equity market volatility will not change the market leverage ratio of the firm with no debt whereas the market leverage ratio of the firm with an average ratio of $50 \%$ will observe significant time series variation in leverage. Time fixed effects capturing market volatility will cause residual variation in the leverage ratio of the zero debt firm to move too much whereas the residual variation will be insufficient for the highly levered firm. This will cause the true tax effect to be under-estimated despite the presence of time fixed effects.
} 
The results are even stronger when we examine net book leverage. The Graham (2006) tax estimates still generate statistically significant negative coefficient estimates. The Blouin, Core, and Guay (2010) tax estimates generate one negative and one positive coefficient estimate, neither statistically different from zero. Contrast that with our tax measure which retains its positive coefficient estimates with better than one percent statistical significance. More interestingly, the coefficient magnitudes are twice the size of the estimated coefficients in the standard book leverage regressions. Comparing a firm with a 35\% effective tax rate to one with a $25 \%$ effective tax rate across its international operations, the higher tax rate confronting firm has on average $6.6 \%$ of book assets more debt net of cash according to the OLS specification results, $14.4 \%$ of book assets more debt net of cash in the between regression specification. Recognize that the average firm in the sample has an amount of debt in excess of its assets equivalent to $14.7 \%$ of its assets. Our effective tax rate measure has a standard deviation of 4.9\% so for roughly a two standard deviation increase in the tax rate confronting a firm, we find a change in net book leverage of a magnitude equivalent to the mean amount of debt net of cash the firm has relative to its assets. These results complement Foley et al (2007) since they too found that lower tax rates are associated with more cash, which would make net leverage ratios lower (our finding).

Moving to net market leverage, the results are again similar to what we documented with net book leverage. In the OLS specification, Graham (2006a) estimates are still negative and statistically significant though in the between specification, the coefficient is not statistically different from zero. The Blouin, Core, and Guay (2010) tax measures are positive and statistically significant in the between effects specification. Our coefficient estimates are likewise positive and statistically significant in both specifications. However, our estimates are 
significantly larger in terms of our economic magnitudes, by a factor of eleven in the OLS specification relative to Blouin, Core, and Guay (2010) and a factor of three in the between effects specification.

\section{Interest Coverage Ratio}

An alternative way to estimate capital structure effects is to look at the portion of a firm's annual earnings obligated to interest expense, an income statement approach rather than a balance sheet approach. Table 6 provides the results of regressing our measure of interest coverage (the natural log of one plus the interest coverage ratio) on the same set of controls and tax rate variables employed above. Similar to the baseline specifications for leverage, rated firms with greater asset tangibility and lower earnings have lower interest coverage ratios (more debt). Firms with greater growth opportunities, as measured by $\mathrm{R} \& \mathrm{D}$, have higher interest coverage ratios, consistent with them wanting to have less of their operating cash flow encumbered by obligatory interest payments that may impede the firm's ability to take advantage of its growth opportunities. Similar to the baseline leverage regressions, we estimate that higher market-to-book ratios and higher advertising expenditures are associated with lower interest coverage ratios for this sample of multinationals, contrary to results obtained for most other samples.

Adding in the Graham (1996a) and Blouin, Core, and Guay (2010) tax variables, we again find that for multinationals over the four year period we examine, firms with higher tax rates have significantly higher interest coverage ratios (less debt). Rather than shielding more of their income from corporate taxation in light of the higher tax rate they would hypothetically confront, they actually have smaller obligatory interest payments relative to the scale of their 
earnings. For the Graham (1996a) measure, the estimated coefficient is statistically significant at better than one percent in the opposite direction of what theory would predict. The Blouin, Core, and Guay (2010) measure is statistically significant at better than one percent in the OLS specification and insignificant in the between regression specification.

Replacing those tax estimate measures with our weighted average tax variable, we find that firms confronting higher tax rates have significantly lower interest coverage ratios, consistent with theory. When firms would have their income subject to a higher tax rate in the year it is earned, the firm appears to obligate more of those earnings to interest payments, thus shielding more of the income from corporate taxation and arrive at a lower interest coverage ratio. Statistically, our coefficient estimates are significant at better than five percent in the OLS specification and better than one percent in the between specification. Economically, a ten percent reduction in the effective tax rate that the firm will confront, given the location and scale of its multinational operations, corresponds to a fifteen percent reduction in the firm's interest coverage ratio in the OLS specification, thirty-one percent in the between specification. Despite the mixed results of previous examinations, our results demonstrate that taxes have the first order relationship with leverage that theory suggests and that forms the basis of the tradeoff theory of capital structure.

\section{Conclusion}

Our results indicate that variation in tax rates is an important consideration in explaining the cross-sectional variation we observe in leverage ratios. Graham (1996a) identified such effects during the sample period he examined which primarily consisted of the 1970s, 1980s, and early 1990s. More recent research has had difficulty in identifying that relationship, although 
Blouin, Core, and Guay (2010)'s alternative estimation technique did identify such an effect for largely domestic firms. As multinational firms have increased over time and more of their operations have been located overseas, understanding the more recent leverage dynamics is an important pursuit for finance researchers. The variation in tax rates across countries and the ability of firms to defer the US tax consequences of those operations has led to tax effect empirical estimates that differ from theory and from historical empirical findings. We contribute to our understanding of that inconsistency by employing proprietary data that enables a more accurate estimate of the true tax rate confronting firms. Our results sustain the theory and early findings that variation in tax rates are indeed of first order importance in explaining leverage.

Irrespective of whether we examine leverage ratios based on book values or market values, whether we include cash or not, or if we alternatively examine interest coverage, we find that multinational firms confronting lower tax rates use less debt. The results are not only statistically significant, but the coefficient magnitudes suggest that these effects are first order; the changes in leverage associated with reasonable moves in estimated tax rates are of magnitudes similar to other well-documented factors explaining variation in corporate debt usage. Also, consistent with the notion that the variation in tax rates firms confront does not vary greatly over time and instead primarily varies across firms, our results are stronger when we solely focus on the cross-sectional variation in our data set (employing between regression specifications) instead of allowing both time-series and cross-sectional variation (the OLS specifications).

As the international component of firms operations increases, the true tax rates that firms confront will continually be less driven by the US tax code. The lack of publicly available data on the international operations of firms will therefore continue to plague efforts by empirical 
researchers looking to understand corporate financial policies. The results in this paper, due to our access to generally unavailable data demonstrates the significant difference in our understanding of corporate financial policies, and the resulting inferences that can be made, when moving from publicly available data to more accurate measures of their operations. These results demonstrate the increasing need for more comprehensive data on the international operations of publicly traded firms to be more fully disclosed. 


\section{References:}

Antras, Pol, Mihir Desai, and C. Fritz Foley, 2009, Multinational firms, fdi flows and imperfect capital markets., Quarterly Journal of Economics 124, 1171-1219.

Bartelsman, E.J., and M.W.J. Beetsma, 2003, Why pay more? Corporate tax avoidance through transfer pricing in OECD countries, Journal of Public Economics 87, 2225-2252.

Blouin, Jennifer, John Core, and Wayne Guay, 2010, Have the tax benefits of debt been overestimated?, Journal of Financial Economics 98, 195-213.

Clausing, K.A., 2003, Tax-motivated transfer pricing and US intrafirm trade prices, Journal of Public Economics 87, 2207-2223.

Desai, Mihir A., 2003, The divergence between book income and tax income., Tax Policy and the Economy 17, 169-206.

Desai, Mihir A., C. Fritz Foley, and Kristin Forbes, 2008, Financial constraints and growth: Multinational and local firm response to currency crises., Review of Financial Studies 21, 2857-2888.

Desai, Mihir A., C. Fritz Foley, and James R. Hines Jr., 2011, Tax policy and the efficiency of U.S. direct investment abroad, National Tax Journal 64, 1055-1082.

Faulkender, Michael, Mark J. Flannery, Kristine W. Hankins, and Jason M. Smith, 2012, Cash flows and leverage adjustments, Journal of Financial Economics 103, 632-646.

Faulkender, M., and Mitchell Petersen, 2006, Does the source of capital affect capital structure?, Review of Financial Studies 19, 45-79.

Faulkender, Michael, and Mitchell Petersen, 2012, Investment and capital constraints:

Repatriations under the American jobs creation act, Review of Financial Studies 25, 3351-3388.

Flannery, Mark, and Kasturi Rangan, 2006, Partial adjustment toward target capital structures, Journal of Financial Economics 79, 469-506.

Foley, C. Fritz, Jay Hartzell, Sheridan Titman, and Garry Twite, 2007, Why do firms hold so much cash?, Journal of Financial Economics 86, 579-607.

Frank, Murray, and Vidhan Goyal, 2009, Capital structure decisions: Which factors are reliably important?, Financial Management 38, 1-37.

Graham, John R., 1996a, Debt and the marginal tax rate, Journal of Financial Economics 41, 41-73. 
Graham, John R., 1996b, Proxies for the corporate marginal tax rate, Journal of Financial Economics 42, 187-221.

Graham, John R., M. Lang, and D. Shackelford, 2004, Employee stock options, corporate taxes, and debt policy, Journal of Finance 59, 1585-1618.

Graham, John R., and Alan L. Tucker, 2006, Tax shelters and corporate debt policy, Journal of Financial Economics 81, 563-594.

Graham, John R., and Mark T. Leary, 2011, A review of capital structure research and directions for the future, Annual Review of Financial Economics 3, 309-345.

Hines, J., 1997, Tax policy and the activities of multinational corporations. In: Auerbach, A. (Ed.), Fiscal Policy: Lessons from Economic Research. MIT Press, Cambridge, MA, 401445.

KPMG International, 2013, Corporate and Indirect Tax Survey 2012, http://www.kpmg.com/global/en/issuesandinsights/articlespublications/pages/corporateindirect-tax-rate-survey.aspx Nov. 2013.

Leary, Mark, and Michael R. Roberts, 2005, Do firms rebalance their capital structures?, Journal of Finance 60, 2575-2619.

Lemmon, Michael, Michael Roberts, and Jamie Zender, 2008, Back to the beginning: Persistence and the cross-section of corporate capital structure, Journal of Finance 60, 2575-2619.

McCoy, Kevin, 2013, Apple CEO defends tax tactics at Senate hearing, USA Today, 26 May 2013.

Myers, S.C., and N. Majluf, 1984, Corporate financing and investment decisions when firms have information that investors do not have, Journal of Financial Economics 13, 187224.

Welch, I., 2004, Capital structure and stock returns, Journal of Political Economy pp. 106-131. 
Table 1

Summary Statistics

\begin{tabular}{|c|c|c|c|c|c|c|c|c|c|c|c|c|}
\hline \multirow[b]{3}{*}{ Firm_efftaxrat } & \multicolumn{4}{|c|}{ Compustat } & \multicolumn{4}{|c|}{ Non-BEA Firms } & \multicolumn{4}{|c|}{ BEA Firms } \\
\hline & Obs & Mean & Median & $\begin{array}{c}\text { St. } \\
\text { Dev. }\end{array}$ & Obs & Mean & Median & $\begin{array}{c}\text { St. } \\
\text { Dev. }\end{array}$ & Obs & Mean & Median & St. Dev. \\
\hline & & & & & & & & & 11,203 & 0.3353 & 0.3375 & 0.0494 \\
\hline Mtr & 38,42 & 0.2560 & 0.3414 & 0.1326 & 27,217 & 0.2350 & 0.3367 & 0.1393 & 11,203 & 0.3069 & 0.3500 & 0.0972 \\
\hline Bcg_mtr & 38,42 & 0.2738 & 0.3235 & 0.0978 & 27,217 & 0.2558 & 0.3041 & 0.1033 & 11,203 & 0.3174 & 0.3410 & 0.0649 \\
\hline MV Lev & 37,18 & 0.2443 & 0.1659 & 0.2529 & 26,157 & 0.2530 & 0.1641 & 0.2672 & 11,029 & 0.2239 & 0.1565 & 0.2138 \\
\hline BV Lev & 38,30 & 0.3754 & 0.2974 & 0.4373 & 27,141 & 0.3838 & 0.2787 & 0.4781 & 11,168 & 0.3549 & 0.3039 & 0.3159 \\
\hline Net MV Lev & 37,18 & 0.1227 & 0.0926 & 0.3383 & 26,155 & 0.1217 & 0.0873 & 0.3635 & 11,029 & 0.1252 & 0.0710 & 0.2696 \\
\hline Net BV Lev & 38,30 & 0.1560 & 0.1788 & 0.5794 & 27,139 & 0.1482 & 0.1597 & 0.6283 & 11,168 & 0.1748 & 0.1476 & 0.4378 \\
\hline Int Cov & $34 \overline{, 90}$ & 44.858 & 5.8409 & 177.88 & 24,210 & 44.254 & 4.2975 & 182.34 & 10,694 & 46.225 & 10.242 & 166.326 \\
\hline Sales $_{i, t-1}$ & 38,42 & 2,189 & 209.5 & 10,717 & 27,217 & 911 & 100.627 & 4,743 & 11,203 & 5292.596 & 1414 & 18,046 \\
\hline Rated $_{i, t}$ & 38,42 & 0.2672 & 0.000 & 0.4425 & 27,217 & .01734 & 0.000 & 0.3786 & 11,203 & 0.4951 & 1.000 & 0.5000 \\
\hline Ppeb $_{i, t}$ & 38,42 & 0.2825 & 0.2177 & 0.2290 & 27,217 & .02889 & 0.2149 & 0.2440 & 11,203 & 0.2668 & 0.1866 & 0.1869 \\
\hline $\operatorname{Roa}_{i, t}$ & 38,42 & 0.0642 & 0.1144 & 0.2309 & 27,217 & 0.0355 & 0.1016 & 0.2592 & 11,203 & 0.1338 & 0.1270 & 0.1127 \\
\hline $\operatorname{Divs}_{i, t}$ & 38,42 & 0.3038 & 0.000 & 0.4877 & 27,217 & 0.3101 & 0.000 & 0.4625 & 11,203 & 0.5828 & 1.000 & 0.4931 \\
\hline$R d_{i, t}$ & 38,42 & 0.1191 & 0.000 & 0.4406 & 27,217 & 0.1486 & 0.000 & 0.5124 & 11,203 & 0.0476 & 0.0106 & 0.1440 \\
\hline$A d v_{i, t}$ & 38,42 & 0.0111 & 0.000 & 0.0602 & 27,217 & 0.0114 & 0.000 & 0.0689 & 11,203 & 0.0106 & 0.000 & 0.0298 \\
\hline$M b_{i, t}$ & 38,42 & 2.2851 & 1.5084 & 2.1616 & 27,217 & 2.4122 & 1.4995 & 2.3684 & 11,203 & 1.9762 & 1.5344 & 1.5040 \\
\hline $\operatorname{Depr}_{i, t}$ & 38,42 & 0.0518 & 0.0414 & 0.0544 & 27,217 & 0.0544 & 0.0419 & 0.0617 & 11,203 & 0.0456 & 0.03633 & 0.0289 \\
\hline
\end{tabular}




\section{Table 2}

\section{Book Leverage Regressions}

The table reports the results from estimating the following OLS equation in columns I-IV:

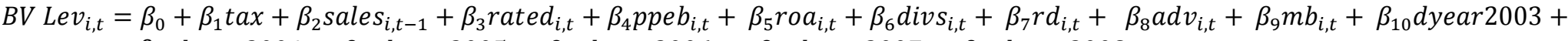
$\beta_{11}$ dyear $2004+\beta_{12}$ dyear $2005+\beta_{13}$ dyear $2006+\beta_{14}$ dyear $2007+\beta_{15}$ dyear $2008+\epsilon_{i, t}$

Columns V-VIII report the results from estimation using between effects which is the OLS estimator applied to the following time-averaged equation:

$$
B V \overline{\operatorname{Lev}_{\iota}}=\beta_{0}+\beta_{1} \text { tax }+\beta_{2} \overline{\text { sales }_{l}}+\beta_{3} \overline{\text { rated }_{\imath}}+\beta_{4} \overline{p p e b_{l}}+\beta_{5} \overline{r o a_{l}}+\beta_{6} \overline{\operatorname{dlvs}_{l}}+\beta_{7} \overline{r d_{l}}+\beta_{8} \overline{a d v_{l}}+\beta_{9} \overline{m b_{l}}+\epsilon_{i, t}
$$

Where $\overline{L e v_{t}}$ represents the average across time, i.e. $\sum_{t=1}^{T} \frac{L e v_{i, t}}{T}$.

The dependent variable is the book value of leverage ( $B V$ Lev) for firm $i$ in year $t$. tax is our measure of the tax rate facing each multinational firm. The base case is in Column I and V, Graham's mtr in Column II and VI, Blouin, Core, and Guay's bcg_mtr in Column III and VII, and our new measure firm_efftaxrate in Column IV and VIII. The independent variables include lagged sales ( sales $\left._{i, t-1}\right)$, a dummy variable to indicate if the firm has a credit rating (rated $\left.{ }_{i, t}\right)$, property, plant, and equipment over lagged book assets $\left(\right.$ ppeb $\left._{i, t}\right)$, return on assets $\left(\right.$ roa $\left._{i, t}\right)$, a dummy variable set to 1 if the firm pays a dividend (divs $\left.i_{i, t}\right)$, research and development expense $\left(r d_{i, t}\right)$, advertising expense $\left(\mathrm{adv}_{\mathrm{i}, \mathrm{t}}\right)$, market-to-book ratio $\left(\mathrm{mb}_{\mathrm{i}, \mathrm{t}}\right)$, and finally year dummy variables (e.g. dyear2007). Standard errors are clustered at the firm level. Standard errors are reported in parenthesis.

***, **, * represent significance at the one percent, five percent, and ten percent levels, respectively. 


\begin{tabular}{|c|c|c|c|c|c|c|c|c|}
\hline & 1 & II & III & IV & V & VI & VII & VIII \\
\hline$M t r_{i, t}$ & & $\begin{array}{c}-0.3570 * * * \\
(0.0593)\end{array}$ & & & & $\begin{array}{c}-0.4455 * * * \\
(0.1038)\end{array}$ & & \\
\hline$B c g \_m t r_{i, t}$ & & & $\begin{array}{c}-0.5453^{* * *} \\
(0.1382)\end{array}$ & & & & $\begin{array}{c}-0.4273 * * * \\
(0.1349)\end{array}$ & \\
\hline Firm_efftaxrate $_{i, t}$ & & & & $\begin{array}{c}0.2688 * * \\
(0.0988)\end{array}$ & & & & $\begin{array}{c}0.7111 * * * \\
(0.1717)\end{array}$ \\
\hline Sales $_{i, t-1}$ & $\begin{array}{c}-0.0112 * * \\
(0.0048)\end{array}$ & $\begin{array}{l}-0.0073 \\
(0.0047)\end{array}$ & $\begin{array}{l}-0.0051 \\
(0.0050)\end{array}$ & $\begin{array}{c}-0.0100 * * \\
(0.0047)\end{array}$ & $\begin{array}{c}-0.0152 * * \\
(0.0061)\end{array}$ & $\begin{array}{c}-0.0103^{*} \\
(0.0061)\end{array}$ & $\begin{array}{c}-0.101 \\
(0.0062)\end{array}$ & $\begin{array}{c}-0.0109 * \\
(0.0061)\end{array}$ \\
\hline Rated $_{i, t}$ & $\begin{array}{c}0.2332^{* * *} \\
(0.0161)\end{array}$ & $\begin{array}{c}0.2301 * * * \\
(0.0159)\end{array}$ & $\begin{array}{c}0.2319 * * * \\
(0.0161)\end{array}$ & $\begin{array}{c}0.2318 * * * \\
(0.0160)\end{array}$ & $\begin{array}{c}0.2612 * * * \\
(0.0224)\end{array}$ & $\begin{array}{c}0.2583 * * * \\
(0.0223)\end{array}$ & $\begin{array}{c}0.2604^{* * * *} \\
(0.0223)\end{array}$ & $\begin{array}{c}0.2562^{* * *} \\
(0.0495)\end{array}$ \\
\hline$P_{p e b_{i, t}}$ & $\begin{array}{c}0.1968 * * * \\
(0.0386)\end{array}$ & $\begin{array}{c}0.1931 * * * \\
(0.0380)\end{array}$ & $\begin{array}{c}0.2050 * * * \\
(0.0386)\end{array}$ & $\begin{array}{c}0.1940 * * * \\
(0.0384)\end{array}$ & $\begin{array}{c}0.2676 * * * \\
(0.0497)\end{array}$ & $\begin{array}{c}0.2681^{* * *} \\
(0.0494)\end{array}$ & $\begin{array}{c}0.2845^{* * *} \\
(0.0498)\end{array}$ & $\begin{array}{c}0.2554 * * * \\
(0.0495)\end{array}$ \\
\hline $\operatorname{Roa}_{i, t}$ & $\begin{array}{c}-0.4177^{* * * *} \\
(0.0868)\end{array}$ & $\begin{array}{c}-0.3092 * * * \\
(0.0841)\end{array}$ & $\begin{array}{c}-0.3006 * * * \\
(0.0880)\end{array}$ & $\begin{array}{c}-0.4204^{* * *} \\
(0.0869)\end{array}$ & $\begin{array}{c}-0.4875 * * * \\
(0.0745)\end{array}$ & $\begin{array}{c}-0.3317 * * * \\
(0.0826)\end{array}$ & $\begin{array}{c}-0.3703^{* * *} \\
(0.0830)\end{array}$ & $\begin{array}{c}-0.5014 * * * \\
(0.0742)\end{array}$ \\
\hline $\operatorname{Divs}_{i, t}$ & $\begin{array}{c}-0.0291 * * \\
(0.0127)\end{array}$ & $\begin{array}{c}-0.0222 * \\
(0.0125)\end{array}$ & $\begin{array}{c}-0.0248 * \\
(0.0127)\end{array}$ & $\begin{array}{c}-0.0303 * * \\
(0.0127)\end{array}$ & $\begin{array}{l}-0.0295 \\
(0.0184)\end{array}$ & $\begin{array}{l}-0.0209 \\
(0.0184)\end{array}$ & $\begin{array}{l}-0.0240 \\
(0.0184)\end{array}$ & $\begin{array}{c}-0.0389 * * \\
(0.0185)\end{array}$ \\
\hline$R d_{i, t}$ & $\begin{array}{l}-0.1255 \\
(0.0830)\end{array}$ & $\begin{array}{l}-0.1366 \\
(0.0836)\end{array}$ & $\begin{array}{c}-0.1462 * \\
(0.0852)\end{array}$ & $\begin{array}{l}-0.1224 \\
(0.0819)\end{array}$ & $\begin{array}{c}-0.1346 * * * \\
(0.0475)\end{array}$ & $\begin{array}{c}-0.1482 * * * \\
(0.0474)\end{array}$ & $\begin{array}{c}-0.1482 * * * \\
(0.0476)\end{array}$ & $\begin{array}{c}-0.1221 * * * \\
(0.0474)\end{array}$ \\
\hline$A d v_{i, t}$ & $\begin{array}{c}0.7100 * * \\
(0.3221)\end{array}$ & $\begin{array}{c}0.6981 * \\
(0.3189)\end{array}$ & $\begin{array}{c}0.6889 * * \\
(0.3257)\end{array}$ & $\begin{array}{c}0.7223 * * \\
(0.3205)\end{array}$ & $\begin{array}{c}0.4534^{*} \\
(0.2730)\end{array}$ & $\begin{array}{c}0.4499 * \\
(0.2716)\end{array}$ & $\begin{array}{c}0.4510^{*} \\
(0.2723)\end{array}$ & $\begin{array}{l}0.4929 * \\
(0.2719)\end{array}$ \\
\hline$M b_{i, t}$ & $\begin{array}{c}0.0087 * * \\
(0.0073)\end{array}$ & $\begin{array}{c}0.0074 \\
(0.0073)\end{array}$ & $\begin{array}{c}0.0066 \\
(0.0075)\end{array}$ & $\begin{array}{c}0.0087 \\
(0.0073)\end{array}$ & $\begin{array}{c}0.0274 * * * \\
(0.0053)\end{array}$ & $\begin{array}{c}0.0260 * * * \\
(0.0053)\end{array}$ & $\begin{array}{c}0.0266^{* * *} \\
(0.0053)\end{array}$ & $\begin{array}{c}0.0272 * * * \\
(0.0052)\end{array}$ \\
\hline $\operatorname{Depr}_{i, t}$ & $\begin{array}{c}0.2574 \\
(0.2742)\end{array}$ & $\begin{array}{c}0.1184 \\
(0.2640)\end{array}$ & $\begin{array}{c}0.0402 \\
(0.2730)\end{array}$ & $\begin{array}{c}0.2655 \\
(0.2741)\end{array}$ & $\begin{array}{c}0.5837 * * \\
(0.2760)\end{array}$ & $\begin{array}{c}0.3812 \\
(0.2786)\end{array}$ & $\begin{array}{c}0.3769 \\
(0.2829)\end{array}$ & $\begin{array}{c}0.5890 * * \\
(0.2747)\end{array}$ \\
\hline $\mathrm{N}$ & 11,168 & 11,168 & 11,168 & 11,168 & 11,168 & 11,168 & 11,168 & 11,168 \\
\hline $\mathrm{R}^{2}$ & 0.1582 & 0.1671 & 0.1650 & 0.1595 & 0.1586 & 0.1672 & 0.1633 & 0.1666 \\
\hline
\end{tabular}




\section{Table 3}

\section{Market Leverage Regressions}

The table reports the results from estimating the following OLS equation in columns I-IV:

MV Lev Le $_{i, t}=\beta_{0}+\beta_{1}$ tax $\beta_{2}$ sales $_{i, t-1}+\beta_{3}$ rated $_{i, t}+\beta_{4}$ ppeb $_{i, t}+\beta_{5}$ roa $_{i, t}+\beta_{6}$ divs $_{i, t}+\beta_{7}$ rd $_{i, t}+\beta_{8}$ adv $_{i, t}+\beta_{9}$ mb $_{i, t}+\beta_{10}$ dyear $2003+$ $\beta_{11}$ dyear $2004+\beta_{12}$ dyear $2005+\beta_{13}$ dyear $2006+\beta_{14}$ dyear $2007+\beta_{15}$ dyear $2008+\epsilon_{i, t}$

Columns V-VIII report the results from estimation using between effects which is the OLS estimator applied to the following time-averaged equation:

$$
M V \overline{\text { evv }_{l}}=\beta_{0}+\beta_{1} \text { tax }+\beta_{2} \overline{\text { sales }_{l}}+\beta_{3} \overline{\text { rated }_{l}}+\beta_{4} \overline{\text { ppeb }_{l}}+\beta_{5} \overline{\text { roa }_{l}}+\beta_{6} \overline{\overline{l v v s}_{l}}+\beta_{7} \overline{r d_{l}}+\beta_{8} \overline{a^{2} v_{l}}+\beta_{9} \overline{m b_{l}}+\epsilon_{i, t}
$$

Where $\overline{L e v_{t}}$ represents the average across time, i.e. $\sum_{t=1}^{T} \frac{L e v_{i, t}}{T}$.

The dependent variable is the market value of leverage ( $M V$ Lev) for firm $i$ in year $t$. tax is our measure of the tax rate facing each multinational firm. The base case is in Column I and V, Graham's mtr in Column II and VI, Blouin, Core, and Guay's bcg_mtr in Column III and VII, and our new measure firm_efftaxrate in Column IV and VIII. The independent variables include lagged sales ( sales $\left._{i, t-1}\right)$, a dummy variable to indicate if the firm has a credit rating $\left(\right.$ rated $\left._{i, t}\right)$, property, plant, and equipment over lagged book assets $\left(\mathrm{ppeb}_{i, t}\right)$, return on assets $\left(r o a_{i, t}\right)$, a dummy variable set to 1 if the firm pays a dividend (divs $\left.\mathrm{s}_{i, t}\right)$, research and development expense $\left(r d_{i, t}\right)$, advertising expense $\left(\mathrm{adv}_{\mathrm{i}, \mathrm{t}}\right)$, market-to-book ratio $\left(\mathrm{mb}_{\mathrm{i}, \mathrm{t}}\right)$, and finally year dummy variables (e.g. dyear2007). Standard errors are clustered at the firm level. Standard errors are reported in parenthesis.

***, **, * represent significance at the one percent, five percent, and ten percent levels, respectively. 


\begin{tabular}{|c|c|c|c|c|c|c|c|c|}
\hline & I & II & III & IV & V & VI & VII & VIII \\
\hline$M t r_{i, t}$ & & $\begin{array}{c}-0.2307 * * * \\
(0.0353)\end{array}$ & & & & $\begin{array}{c}-0.3244^{* * *} \\
(0.0609)\end{array}$ & & \\
\hline Bcg_mtr $r_{i, t}$ & & & $\begin{array}{c}-0.3296 * * * \\
(0.0876)\end{array}$ & & & & $\begin{array}{c}-0.3088 * * * \\
(0.0791)\end{array}$ & \\
\hline Firm_efftaxrate $_{i, t}$ & & & & $\begin{array}{c}0.0609 \\
(0.0680)\end{array}$ & & & & $\begin{array}{c}0.2922 * * * \\
(0.1006)\end{array}$ \\
\hline Sales $_{i, t-1}$ & $\begin{array}{c}-0.0112 * * * \\
(0.0034)\end{array}$ & $\begin{array}{c}-0.0087 * * \\
(0.0034)\end{array}$ & $\begin{array}{c}-0.0075^{* *} \\
(0.0035)\end{array}$ & $\begin{array}{c}-0.0110 * * * \\
(0.0035)\end{array}$ & $\begin{array}{c}-0.0094 * * * \\
(0.0036)\end{array}$ & $\begin{array}{c}-0.0060 * \\
(0.0036)\end{array}$ & $\begin{array}{l}-0.0058 \\
(0.0037)\end{array}$ & $\begin{array}{c}-0.0076^{* *} \\
(0.0036)\end{array}$ \\
\hline Rated $_{i, t}$ & $\begin{array}{c}0.1243 * * * \\
(0.0097)\end{array}$ & $\begin{array}{c}0.1222 * * * \\
(0.0097)\end{array}$ & $\begin{array}{c}0.01233 * * * \\
(0.0098)\end{array}$ & $\begin{array}{c}0.1240 * * * \\
(0.0098)\end{array}$ & $\begin{array}{c}0.1362 * * * \\
(0.0132)\end{array}$ & $\begin{array}{c}0.1340 * * * \\
(0.0131)\end{array}$ & $\begin{array}{c}0.1351 * * * \\
(0.0132)\end{array}$ & $\begin{array}{c}0.1344 * * * \\
(0.0132)\end{array}$ \\
\hline$P_{p e b} b_{i, t}$ & $\begin{array}{c}0.1988 * * * \\
(0.0248)\end{array}$ & $\begin{array}{c}0.1962 * * * \\
(0.0245)\end{array}$ & $\begin{array}{c}0.2029 * * * \\
(0.0248)\end{array}$ & $\begin{array}{c}0.1982 * * * \\
(0.0248)\end{array}$ & $\begin{array}{c}0.2322 * * * \\
(0.0296)\end{array}$ & $\begin{array}{c}0.2324 * * * \\
(0.0293)\end{array}$ & $\begin{array}{c}0.2431 * * * \\
(0.0296)\end{array}$ & $\begin{array}{c}0.2277 * * * \\
(0.0295)\end{array}$ \\
\hline $\operatorname{Roa}_{i, t}$ & $\begin{array}{c}-0.3474 * * * \\
(0.0080)\end{array}$ & $\begin{array}{c}-0.2763^{* * *} \\
(0.0356)\end{array}$ & $\begin{array}{c}-0.2716^{* * *} \\
(0.0399)\end{array}$ & $\begin{array}{c}-0.3484 * * * \\
(0.0366)\end{array}$ & $\begin{array}{c}-0.2639 * * * \\
(0.0452)\end{array}$ & $\begin{array}{c}-0.1514^{* * *} \\
(0.0496)\end{array}$ & $\begin{array}{c}-0.1737^{* * *} \\
(0.0506)\end{array}$ & $\begin{array}{c}-0.2715^{* * *} \\
(0.0452)\end{array}$ \\
\hline $\operatorname{Divs}_{i, t}$ & $\begin{array}{c}-0.0340 * * * \\
(0.0080)\end{array}$ & $\begin{array}{c}-0.0295 * * * \\
(0.0079)\end{array}$ & $\begin{array}{c}-0.0314^{* * *} \\
(0.0079)\end{array}$ & $\begin{array}{c}-0.0343 * * * \\
(0.0080)\end{array}$ & $\begin{array}{c}-0.0448 * * * \\
(0.0108)\end{array}$ & $\begin{array}{c}-0.0382 * * * \\
(0.0108)\end{array}$ & $\begin{array}{c}-0.0406 * * * \\
(0.0108)\end{array}$ & $\begin{array}{c}-0.0488 * * * \\
(0.0109)\end{array}$ \\
\hline$R d_{i, t}$ & $\begin{array}{c}-0.1399 * * * \\
(0.0389)\end{array}$ & $\begin{array}{c}-0.1461 * * * \\
(0.0389)\end{array}$ & $\begin{array}{c}-0.01488 * * * \\
(0.0397)\end{array}$ & $\begin{array}{c}-0.1394 * * * \\
(0.3865)\end{array}$ & $\begin{array}{c}-0.1048 * * * \\
(0.0291)\end{array}$ & $\begin{array}{c}-0.1152 * * * \\
(0.0289)\end{array}$ & $\begin{array}{c}-0.1105^{* * *} \\
(0.0290)\end{array}$ & $\begin{array}{c}-0.1009 * * * \\
(0.0290)\end{array}$ \\
\hline$A d v_{i, t}$ & $\begin{array}{c}0.1201 \\
(0.1267)\end{array}$ & $\begin{array}{c}0.1176 \\
(0.1278)\end{array}$ & $\begin{array}{c}0.1116 \\
(0.1303)\end{array}$ & $\begin{array}{c}0.1227 \\
(0.1264)\end{array}$ & $\begin{array}{c}0.0208 \\
(0.1651)\end{array}$ & $\begin{array}{c}0.0236 \\
(0.1638)\end{array}$ & $\begin{array}{c}0.0238 \\
(0.1644)\end{array}$ & $\begin{array}{c}0.0326 \\
(0.0109)\end{array}$ \\
\hline$M b_{i, t}$ & $\begin{array}{c}-0.0548 * * * \\
(0.0041)\end{array}$ & $\begin{array}{c}-0.0560 * * * \\
(0.0040)\end{array}$ & $\begin{array}{c}-0.0572 * * * \\
(0.0039)\end{array}$ & $\begin{array}{l}-0.0547 \\
(0.0041)\end{array}$ & $\begin{array}{c}-0.0672 * * * \\
(0.0050)\end{array}$ & $\begin{array}{c}-0.0680 * * * \\
(0.0050)\end{array}$ & $\begin{array}{c}-0.0696 * * * \\
(0.0050)\end{array}$ & $\begin{array}{c}-0.0667 * * * \\
(0.0050)\end{array}$ \\
\hline$D e p r_{i, t}$ & $\begin{array}{c}-0.2455^{*} \\
(0.1447)\end{array}$ & $\begin{array}{c}-0.3372 * * \\
(0.1384)\end{array}$ & $\begin{array}{c}-0.3791 * * * \\
(0.1447)\end{array}$ & $\begin{array}{c}-0.2436 * \\
(0.1446)\end{array}$ & $\begin{array}{l}-0.0165 \\
(0.1618)\end{array}$ & $\begin{array}{c}-0.1667 \\
(0.1630)\end{array}$ & $\begin{array}{c}-0.1637 \\
(0.1655)\end{array}$ & $\begin{array}{l}-0.0159 \\
(0.1614)\end{array}$ \\
\hline $\mathrm{N}$ & 11,029 & 11,029 & 11,029 & 11,029 & 11,029 & 11,029 & 11,029 & 11,029 \\
\hline $\mathrm{R}^{2}$ & 0.3101 & 0.3181 & 0.3155 & 0.3102 & 0.2759 & 0.2874 & 0.2822 & 0.2794 \\
\hline
\end{tabular}




\section{Table 4}

\section{Net Book Leverage Regressions}

The table reports the results from estimating the following OLS equation in columns I-IV:

Net BV Lev Le $_{i, t}=\beta_{0}+\beta_{1}$ tax $+\beta_{2}$ sales $_{i, t-1}+\beta_{3}$ rated $_{i, t}+\beta_{4}$ ppeb $_{i, t}+\beta_{5}$ roa $_{i, t}+\beta_{6}$ divs $_{i, t}+\beta_{7}$ rd $_{i, t}+\beta_{8}$ adv $_{i, t}+\beta_{9}$ mb $_{i, t}+\beta_{10}$ dyear $2003++$ $\beta_{11}$ dyear $2004+\beta_{12}$ dyear $2005+\beta_{13}$ dyear $2006+\beta_{14}$ dyear $2007+\beta_{15}$ dyear $2008+\epsilon_{i, t}$

Columns V-VIII report the results from estimation using between effects which is the OLS estimator applied to the following time-averaged equation:

$$
\text { Net BV } \overline{\text { Lev }_{l}}=\beta_{0}+\beta_{1} \text { tax }+\beta_{2} \overline{\text { sales }_{l}}+\beta_{3} \overline{\text { rated }_{\iota}}+\beta_{4} \overline{\text { ppeb }_{l}}+\beta_{5} \overline{\text { roa }_{\iota}}+\beta_{6} \overline{d_{l v s_{l}}}+\beta_{7} \overline{r d_{l}}+\beta_{8} \overline{a d v_{l}}+\beta_{9} \overline{m b_{l}}+\epsilon_{i, t}
$$

Where $\overline{\operatorname{Lev}_{t}}$ represents the average across time, i.e. $\sum_{t=1}^{T} \frac{\operatorname{Lev} v_{i, t}}{T}$.

The dependent variable is net book value of leverage (Net BV Lev) for firm $i$ in year t. tax is our measure of the tax rate facing each multinational firm. The base case is in Column I and V, Graham's mtr in Column II and VI, Blouin, Core, and Guay's bcg_mtr in Column III and VII, and our new measure firm_efftaxrate in Column IV and VIII. The independent variables include lagged sales ( sales $\left._{i, t-1}\right)$, a dummy variable to indicate if the firm has a credit rating $\left(\right.$ rated $\left._{i, t}\right)$, property, plant, and equipment over lagged book assets $\left(\mathrm{ppeb}_{i, t}\right)$, return on assets $\left(r o a_{i, t}\right)$, a dummy variable set to 1 if the firm pays a dividend (divs $\left.\mathrm{s}_{i, t}\right)$, research and development expense $\left(r d_{i, t}\right)$, advertising expense $\left(\mathrm{adv}_{\mathrm{i}, \mathrm{t}}\right)$, market-to-book ratio $\left(\mathrm{mb}_{\mathrm{i}, \mathrm{t}}\right)$, and finally year dummy variables (e.g. dyear2007). Standard errors are clustered at the firm level. Standard errors are reported in parenthesis.

***, **, * represent significance at the one percent, five percent, and ten percent levels, respectively. 


\begin{tabular}{|c|c|c|c|c|c|c|c|c|}
\hline & 1 & II & III & IV & $\mathrm{V}$ & VI & VII & VIII \\
\hline$M t r_{i, t}$ & & $\begin{array}{c}-0.2354 * * * \\
(0.0782)\end{array}$ & & & & $\begin{array}{c}-0.2909 * * \\
(0.1324)\end{array}$ & & \\
\hline Bcg_mtr $r_{i, t}$ & & & $\begin{array}{l}-0.0969 \\
(0.1766)\end{array}$ & & & & $\begin{array}{c}0.2345 \\
(0.1718)\end{array}$ & \\
\hline Firm_efftaxrate $_{i, t}$ & & & & $\begin{array}{c}0.6663 * * * \\
(0.1525)\end{array}$ & & & & $\begin{array}{c}1.4416^{* * *} \\
(0.2166)\end{array}$ \\
\hline Sales $_{i, t-1}$ & $\begin{array}{c}-0.0075 \\
(0.0070)\end{array}$ & $\begin{array}{l}-0.0049 \\
(0.0070)\end{array}$ & $\begin{array}{l}-0.0064 \\
(0.0072)\end{array}$ & $\begin{array}{l}-0.0047 \\
(0.0068)\end{array}$ & $\begin{array}{c}-0.0184^{* *} \\
(0.0077)\end{array}$ & $\begin{array}{c}-0.0155^{* *} \\
(0.0078)\end{array}$ & $\begin{array}{c}-0.0211^{* * *} \\
(0.0080)\end{array}$ & $\begin{array}{l}-0.0096 \\
(0.0077)\end{array}$ \\
\hline Rated $_{i, t}$ & $\begin{array}{c}0.2699 * * * \\
(0.0216)\end{array}$ & $\begin{array}{c}0.2678 \\
(0.0216)\end{array}$ & $\begin{array}{c}0.2697 * * * \\
(0.0216)\end{array}$ & $\begin{array}{c}0.2664 * * * \\
(0.0214)\end{array}$ & $\begin{array}{c}0.3138 * * * \\
(0.0285)\end{array}$ & $\begin{array}{c}0.3121 * * * \\
(0.0285)\end{array}$ & $\begin{array}{c}0.3143 * * * \\
(0.0285)\end{array}$ & $\begin{array}{c}0.3037 * * * \\
(0.0282)\end{array}$ \\
\hline Ppeb $_{i, t}$ & $\begin{array}{c}0.4721 * * * \\
(0.0506)\end{array}$ & $\begin{array}{c}0.4697 * * * \\
(0.0503)\end{array}$ & $\begin{array}{c}0.4736 * * * \\
(0.0505)\end{array}$ & $\begin{array}{c}0.4652 * * * \\
(0.0501)\end{array}$ & $\begin{array}{c}0.5825 * * * \\
(0.0631)\end{array}$ & $\begin{array}{c}0.5828 * * * \\
(0.0630)\end{array}$ & $\begin{array}{c}0.5732^{* * *} \\
(0.0634)\end{array}$ & $\begin{array}{c}0.5577 * * * \\
(0.0625)\end{array}$ \\
\hline $\operatorname{Roa}_{i, t}$ & $\begin{array}{c}-0.3552 * * * \\
(0.1092)\end{array}$ & $\begin{array}{c}-0.2836 * * * \\
(0.1099)\end{array}$ & $\begin{array}{c}-0.3344 * * * \\
(0.1164)\end{array}$ & $\begin{array}{c}-0.3619 * * * \\
(0.1089)\end{array}$ & $\begin{array}{c}-0.4048 * * * \\
(0.0947)\end{array}$ & $\begin{array}{c}-0.3100 * * * \\
(0.1053)\end{array}$ & $\begin{array}{c}-0.4691 * * * \\
(0.1057)\end{array}$ & $\begin{array}{c}-0.4329 * * * \\
(0.0936)\end{array}$ \\
\hline $\operatorname{Divs}_{i, t}$ & $\begin{array}{c}0.0154 \\
(0.0184)\end{array}$ & $\begin{array}{c}0.0199 \\
(0.0182)\end{array}$ & $\begin{array}{c}0.0161 \\
(0.0184)\end{array}$ & $\begin{array}{c}0.0123 \\
(0.0182)\end{array}$ & $\begin{array}{c}0.0258 \\
(0.0234)\end{array}$ & $\begin{array}{c}0.0310 \\
(0.0235)\end{array}$ & $\begin{array}{c}0.0228 \\
(0.0235)\end{array}$ & $\begin{array}{c}0.0068 \\
(0.0233)\end{array}$ \\
\hline$R d_{i, t}$ & $\begin{array}{c}-0.4803 * * * \\
(0.1471)\end{array}$ & $\begin{array}{c}-0.4876 * * * \\
(0.1481)\end{array}$ & $\begin{array}{c}-0.4840 * * * \\
(0.1472)\end{array}$ & $\begin{array}{c}-0.4727 * * * \\
(0.1441)\end{array}$ & $\begin{array}{c}-0.5050 * * * \\
(0.0604)\end{array}$ & $\begin{array}{c}-0.5133^{* * *} \\
(0.0604)\end{array}$ & $\begin{array}{c}-0.4976 * * * \\
(0.0606)\end{array}$ & $\begin{array}{c}-0.4797 * * * \\
(0.0598)\end{array}$ \\
\hline$A d v_{i, t}$ & $\begin{array}{l}0.7158 * \\
(0.3941)\end{array}$ & $\begin{array}{l}0.7079 * \\
(0.3926)\end{array}$ & $\begin{array}{l}0.7120 * \\
(0.3953)\end{array}$ & $\begin{array}{l}0.7463 * \\
(0.3903)\end{array}$ & $\begin{array}{c}0.5022 \\
(0.3468)\end{array}$ & $\begin{array}{c}0.5000 \\
(0.3465)\end{array}$ & $\begin{array}{c}0.5035 \\
(0.3467)\end{array}$ & $\begin{array}{l}0.5821^{*} \\
(0.3429)\end{array}$ \\
\hline$M b_{i, t}$ & $\begin{array}{l}-0.0141 \\
(0.0099)\end{array}$ & $\begin{array}{l}-0.0150 \\
(0.0099)\end{array}$ & $\begin{array}{l}-0.0145 \\
(0.0100)\end{array}$ & $\begin{array}{l}-0.0140 \\
(0.0098)\end{array}$ & $\begin{array}{l}0.0123 * \\
(0.0067)\end{array}$ & $\begin{array}{l}0.0115^{*} \\
(0.0067)\end{array}$ & $\begin{array}{l}0.0127^{*} \\
(0.0067)\end{array}$ & $\begin{array}{l}0.0119 * \\
(0.0066)\end{array}$ \\
\hline $\operatorname{Depr}_{i, t}$ & $\begin{array}{l}-0.1817 \\
(0.3609)\end{array}$ & $\begin{array}{l}-0.2734 \\
(0.3559)\end{array}$ & $\begin{array}{l}-0.2203 \\
(0.3677)\end{array}$ & $\begin{array}{l}-0.1617 \\
(0.3600)\end{array}$ & $\begin{array}{c}0.0909 \\
(0.3506)\end{array}$ & $\begin{array}{l}-0.0322 * \\
(0.0550)\end{array}$ & $\begin{array}{c}0.2044 \\
(0.3603)\end{array}$ & $\begin{array}{c}0.1016 \\
(0.3464)\end{array}$ \\
\hline $\begin{array}{l}\mathrm{N} \\
\mathrm{R}^{2}\end{array}$ & $\begin{array}{l}11,168 \\
0.2114\end{array}$ & $\begin{array}{l}11,168 \\
0.2134\end{array}$ & $\begin{array}{l}11,168 \\
0.2115\end{array}$ & $\begin{array}{l}11,168 \\
0.2157\end{array}$ & $\begin{array}{l}11,168 \\
0.2172\end{array}$ & $\begin{array}{l}11,168 \\
0.2190\end{array}$ & $\begin{array}{l}11,168 \\
0.2180\end{array}$ & $\begin{array}{l}11,168 \\
0.2361\end{array}$ \\
\hline
\end{tabular}




\section{Table 5}

\section{Net Market Leverage Regressions}

The table reports the results from estimating the following OLS equation in columns I-IV:

Net MV Lev L $_{i, t}=\beta_{0}+\beta_{1}$ tax $+\beta_{2}$ sales $_{i, t-1}+\beta_{3}$ rated $_{i, t}+\beta_{4}$ ppeb $_{i, t}+\beta_{5}$ roa $_{i, t}+\beta_{6}$ divs $_{i, t}+\beta_{7}$ rd $_{i, t}+\beta_{8}$ adv $_{i, t}+\beta_{9}$ mb $b_{i, t}+\beta_{10}$ dyear2003 + $\beta_{11}$ dyear $2004+\beta_{12}$ dyear $2005+\beta_{13}$ dyear $2006+\beta_{14}$ dyear $2007+\beta_{15}$ dyear $2008+\epsilon_{i, t}$

Columns V-VIII report the results from estimation using between effects which is the OLS estimator applied to the following time-averaged equation:

$$
\text { Net } M V \overline{\text { Lev }_{l}}=\beta_{0}+\beta_{1} \text { tax }+\beta_{2} \overline{\text { sales }_{l}}+\beta_{3} \overline{\text { rated }_{l}}+\beta_{4} \overline{p_{p e b}}+\beta_{5} \overline{r o a_{l}}+\beta_{6} \overline{\overline{d v v s}_{l}}+\beta_{7} \overline{r d_{l}}+\beta_{8} \overline{a d v_{l}}+\beta_{9} \overline{m b_{l}}+\epsilon_{i, t}
$$

Where $\overline{L e v_{t}}$ represents the average across time, i.e. $\sum_{t=1}^{T} \frac{\operatorname{Lev} v_{i, t}}{T}$.

The dependent variable is the net market value of leverage ( Net MV Lev) for firm $i$ in year $t$. tax is our measure of the tax rate facing each multinational firm. The base case is in Column I and V, Graham's mtr in Column II and VI, Blouin, Core, and Guay's bcg_mtr in Column III and VII, and our new measure firm_efftaxrate in Column IV and VIII. The independent variables include lagged sales (sales $\left.{ }_{i, t-1}\right)$, a dummy variable to indicate if the firm has a credit rating $\left(\right.$ rated $\left._{i, t}\right)$, property, plant, and equipment over lagged book assets $\left(\right.$ ppeb $\left._{i, t}\right)$, return on assets $\left(r o a_{i, t}\right)$, a dummy variable set to 1 if the firm pays a dividend $\left(\right.$ divs $\left._{i, t}\right)$, research and development expense $\left(r d_{i, t}\right)$, advertising expense $\left(\mathrm{adv}_{\mathrm{i}, t}\right)$, market-to-book ratio $\left(\mathrm{mb}_{\mathrm{i}, \mathrm{t}}\right)$, and finally year dummy variables (e.g. dyear2007). Standard errors are clustered at the firm level. Standard errors are reported in parenthesis.

***, **, * represent significance at the one percent, five percent, and ten percent levels, respectively. 


\begin{tabular}{|c|c|c|c|c|c|c|c|c|}
\hline & 1 & II & III & IV & $\mathrm{V}$ & VI & VII & VIII \\
\hline$M t r_{i, t}$ & & $\begin{array}{c}-0.1049 * * \\
(0.0468)\end{array}$ & & & & $\begin{array}{l}-0.0156 \\
(0.0843)\end{array}$ & & \\
\hline Bcg_mtr $r_{i, t}$ & & & $\begin{array}{c}0.0213 \\
(0.1185)\end{array}$ & & & & $\begin{array}{c}0.3122 * * * \\
(0.1089)\end{array}$ & \\
\hline Firm_efftaxrate $_{i, t}$ & & & & $\begin{array}{c}0.2550 * * * \\
(0.0955)\end{array}$ & & & & $\begin{array}{c}0.8958 * * * \\
(0.1368)\end{array}$ \\
\hline Sales $_{i, t-1}$ & $\begin{array}{c}-0.0050 \\
(0.0044)\end{array}$ & $\begin{array}{l}-0.0039 \\
(0.0045)\end{array}$ & $\begin{array}{l}-0.0053 \\
(0.0045)\end{array}$ & $\begin{array}{l}-0.0039 \\
(0.0044)\end{array}$ & $\begin{array}{c}-0.0085^{*} \\
(0.0049)\end{array}$ & $\begin{array}{c}-0.0084 * \\
(0.0843)\end{array}$ & $\begin{array}{c}-0.0122 * * \\
(0.0051)\end{array}$ & $\begin{array}{l}-0.0031 \\
(0.0049)\end{array}$ \\
\hline Rated $_{i, t}$ & $\begin{array}{c}0.1456 * * * \\
(0.0125)\end{array}$ & $\begin{array}{c}0.1447 * * * \\
(0.0125)\end{array}$ & $\begin{array}{c}0.1457 * * * \\
(0.0125)\end{array}$ & $\begin{array}{c}0.1444 * * * \\
(0.0125)\end{array}$ & $\begin{array}{c}0.1764 * * * \\
(0.0181)\end{array}$ & $\begin{array}{c}0.1763 * * * \\
(0.0182)\end{array}$ & $\begin{array}{c}0.1775 * * * \\
(0.0181)\end{array}$ & $\begin{array}{c}0.1708 * * * \\
(0.0179)\end{array}$ \\
\hline Ppeb $_{i, t}$ & $\begin{array}{c}0.3320 * * * \\
(0.0296)\end{array}$ & $\begin{array}{c}0.3309 * * * \\
(0.0296)\end{array}$ & $\begin{array}{l}0.3318 * * * \\
(0.02962)\end{array}$ & $\begin{array}{c}0.3296 * * * \\
(0.0295)\end{array}$ & $\begin{array}{c}0.3986 * * * \\
(0.0406)\end{array}$ & $\begin{array}{c}0.3986 * * * \\
(0.0406)\end{array}$ & $\begin{array}{c}0.3875 * * * \\
(0.0407)\end{array}$ & $\begin{array}{c}0.3848 * * * \\
(0.0402)\end{array}$ \\
\hline $\operatorname{Roa}_{i, t}$ & $\begin{array}{c}-0.1980 * * * \\
(0.0490)\end{array}$ & $\begin{array}{c}-0.1657 * * * \\
(0.0496)\end{array}$ & $\begin{array}{c}-0.2029 * * * \\
(0.0528)\end{array}$ & $\begin{array}{c}-0.2019 * * * \\
(0.0486)\end{array}$ & $\begin{array}{l}-0.0654 \\
(0.0621)\end{array}$ & $\begin{array}{l}-0.0600 \\
(0.0686)\end{array}$ & $\begin{array}{c}-0.1567 * * \\
(0.0696)\end{array}$ & $\begin{array}{l}-0.0884 \\
(0.0614)\end{array}$ \\
\hline $\operatorname{Divs}_{i, t}$ & $\begin{array}{l}-0.0046 \\
(0.0105)\end{array}$ & $\begin{array}{l}-0.0026 \\
(0.0104)\end{array}$ & $\begin{array}{l}-0.0048 \\
(0.0105)\end{array}$ & $\begin{array}{c}-0.0058 \\
(0.0105)\end{array}$ & $\begin{array}{l}-0.0069 \\
(0.0149)\end{array}$ & $\begin{array}{l}-0.0066 \\
(0.0150)\end{array}$ & $\begin{array}{l}-0.0111 \\
(0.0149)\end{array}$ & $\begin{array}{l}-0.0191 \\
(0.0148)\end{array}$ \\
\hline$R d_{i, t}$ & $\begin{array}{c}-0.2256 * * * \\
(0.0638)\end{array}$ & $\begin{array}{c}-0.2284 * * * \\
(0.0642)\end{array}$ & $\begin{array}{c}-0.2250 * * * \\
(0.0642)\end{array}$ & $\begin{array}{c}-0.2235 * * * \\
(0.0628)\end{array}$ & $\begin{array}{c}-0.1843 * * * \\
(0.0399)\end{array}$ & $\begin{array}{c}-0.1848 * * * \\
(0.0399)\end{array}$ & $\begin{array}{c}-0.1785 * * * \\
(0.0399)\end{array}$ & $\begin{array}{c}-0.1723 * * * \\
(0.0395)\end{array}$ \\
\hline$A d v_{i, t}$ & $\begin{array}{c}0.0209 \\
(0.1778)\end{array}$ & $\begin{array}{c}0.0197 \\
(0.1786)\end{array}$ & $\begin{array}{c}0.0214 \\
(0.1776)\end{array}$ & $\begin{array}{c}0.0318 \\
(0.1768)\end{array}$ & $\begin{array}{c}-0.1641 \\
(0.2267)\end{array}$ & $\begin{array}{c}-0.1639 \\
(0.2267)\end{array}$ & $\begin{array}{c}-0.1670 \\
(0.2262)\end{array}$ & $\begin{array}{c}-0.1280 \\
(0.2241)\end{array}$ \\
\hline$M b_{i, t}$ & $\begin{array}{c}-0.0388 * * * \\
(0.0045)\end{array}$ & $\begin{array}{c}-0.0393 * * * \\
(0.0045)\end{array}$ & $\begin{array}{c}-0.0386 * * * \\
(0.0045)\end{array}$ & $\begin{array}{c}-0.0385 * * * \\
(0.0045)\end{array}$ & $\begin{array}{c}-0.0434^{* * *} \\
(0.0069)\end{array}$ & $\begin{array}{c}-0.0435 * * * \\
(0.0069)\end{array}$ & $\begin{array}{c}-0.0410 * * * \\
(0.0069)\end{array}$ & $\begin{array}{c}-0.0420 * * * \\
(0.0068)\end{array}$ \\
\hline Depr $_{i, t}$ & $\begin{array}{c}-0.5360 * * * \\
(0.1767)\end{array}$ & $\begin{array}{c}-0.5777 * * * \\
(0.1777)\end{array}$ & $\begin{array}{c}-0.5273^{* * *} \\
(0.1838)\end{array}$ & $\begin{array}{c}-0.5281^{* * *} \\
(0.1756)\end{array}$ & $\begin{array}{c}-0.2533 \\
(0.2221)\end{array}$ & $\begin{array}{c}-0.2605 \\
(0.2256)\end{array}$ & $\begin{array}{c}-0.1045 \\
(0.2276)\end{array}$ & $\begin{array}{c}-0.2515 \\
(0.2195)\end{array}$ \\
\hline $\begin{array}{l}\mathrm{N} \\
\mathrm{R}^{2}\end{array}$ & $\begin{array}{l}11,029 \\
0.2344\end{array}$ & $\begin{array}{l}11,029 \\
0.2355\end{array}$ & $\begin{array}{l}11,029 \\
0.2345\end{array}$ & $\begin{array}{l}11,029 \\
0.2361\end{array}$ & $\begin{array}{l}11,029 \\
0.2249\end{array}$ & $\begin{array}{l}11,029 \\
0.2249\end{array}$ & $\begin{array}{l}11,029 \\
0.2285\end{array}$ & $\begin{array}{l}11,029 \\
0.2434\end{array}$ \\
\hline
\end{tabular}




\section{Table 6}

\section{Interest Coverage Regressions}

The table reports the results from estimating the following OLS equation in columns I-IV:

$\beta_{0}+\beta_{1}$ tax $+\beta_{2}$ sales $_{i, t-1}+\beta_{3}$ rated $_{i, t}+\beta_{4}$ ppeb $_{i, t}+\beta_{5}$ roa $_{i, t}+\beta_{6}$ divs $_{i, t}+\beta_{7} r d_{i, t}+\beta_{8}$ adv $_{i, t}+\beta_{9}$ mb $_{i, t}+\beta_{10}$ dyear $2003+$ $\beta_{11}$ dyear $2004+\beta_{12}$ dyear $2005+\beta_{13}$ dyear $2006+\beta_{14}$ dyear $2007+\beta_{15}$ dyear $2008+\epsilon_{i, t}$

Columns V-VIII report the results from estimation using between effects which is the OLS estimator applied to the following time-averaged equation:

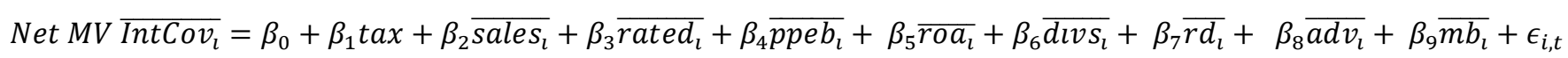

Where $\overline{\operatorname{IntCov_{t}}}$ represents the average across time, i.e. $\sum_{t=1}^{T} \frac{\operatorname{Int} \operatorname{Cov}_{i, t}}{T}$.

The dependent variable is the interest coverage (IntCov) for firm $i$ in year $t$. tax is our measure of the tax rate facing each multinational firm. The base case is in Column I and V, Graham's mtr in Column II and VI, Blouin, Core, and Guay's bcg_mtr in Column III and VII, and our new measure firm_efftaxrate in Column IV and VIII. The independent variables include lagged sales (sales $\left.s_{i, t-1}\right)$, a dummy variable to indicate if the firm has a credit rating $\left(\right.$ rated $_{i, t}$ ), property, plant, and equipment over lagged book assets $\left(p p e b_{i, t}\right)$, return on assets $\left(r o a_{i, t}\right)$, a dummy variable set to 1 if the firm pays a dividend (divs $\left.s_{i, t}\right)$, research and development expense $\left(r d_{i, t}\right)$, advertising expense $\left(\mathrm{adv}_{\mathrm{i}, \mathrm{t}}\right)$, market-to-book ratio $\left(\mathrm{mb}_{\mathrm{i}, \mathrm{t}}\right)$, and finally year dummy variables (e.g. dyear2007). Standard errors are clustered at the firm level. Standard errors are reported in parenthesis.

$* * *, * *, *$ represent significance at the one percent, five percent, and ten percent levels, respectively. 


\begin{tabular}{|c|c|c|c|c|c|c|c|c|}
\hline & I & II & III & IV & V & VI & VII & VIII \\
\hline$M t r_{i, t}$ & & $\begin{array}{c}2.1124 * * * \\
(0.3258)\end{array}$ & & & & $\begin{array}{c}2.7893 * * * \\
(0.5716)\end{array}$ & & \\
\hline Bcg_mtr $r_{i, t}$ & & & $\begin{array}{c}2.9903 * * * \\
(0.7965)\end{array}$ & & & & $\begin{array}{c}1.1021 \\
(0.7433)\end{array}$ & \\
\hline Firm_efftaxrate $_{i, t}$ & & & & $\begin{array}{c}-1.5665 * * \\
(0.7731)\end{array}$ & & & & $\begin{array}{c}-3.1787 * * * \\
(0.9246)\end{array}$ \\
\hline Sales $_{i, t-1}$ & $\begin{array}{c}0.0424 \\
(0.0305)\end{array}$ & $\begin{array}{c}0.0195 \\
(0.0303)\end{array}$ & $\begin{array}{c}0.0098 \\
(0.0303)\end{array}$ & $\begin{array}{c}0.0360 \\
(0.0305)\end{array}$ & $\begin{array}{l}-0.0115 \\
(0.0328)\end{array}$ & $\begin{array}{l}-0.0391 \\
(0.0331)\end{array}$ & $\begin{array}{l}-0.0233 \\
(0.0338)\end{array}$ & $\begin{array}{l}-0.0305 \\
(0.0332)\end{array}$ \\
\hline Rated $_{i, t}$ & $\begin{array}{c}-1.1086^{* * *} \\
(0.0825)\end{array}$ & $\begin{array}{c}-1.0889 * * * \\
(0.0817)\end{array}$ & $\begin{array}{c}-1.103^{* * *} \\
(0.0829)\end{array}$ & $\begin{array}{c}-1.1006^{* * *} \\
(0.0820)\end{array}$ & $\begin{array}{c}-1.0947^{* * *} \\
(0.1204)\end{array}$ & $\begin{array}{c}-1.0764 * * * \\
(0.1197)\end{array}$ & $\begin{array}{c}-1.0945^{* * *} \\
(0.1203)\end{array}$ & $\begin{array}{c}-1.0730 * * * \\
(0.1202)\end{array}$ \\
\hline Ppeb $_{i, t}$ & $\begin{array}{c}-1.2647^{* * *} \\
(0.1759)\end{array}$ & $\begin{array}{c}-1.2369 * * * \\
(0.1724)\end{array}$ & $\begin{array}{c}-1.309 * * * \\
(0.1744)\end{array}$ & $\begin{array}{c}-1.2484 * * * \\
(0.1751)\end{array}$ & $\begin{array}{c}-1.7568 * * * \\
(0.2678)\end{array}$ & $\begin{array}{c}-1.7488 * * * \\
(0.2661)\end{array}$ & $\begin{array}{c}-1.7950 * * * \\
(0.2689)\end{array}$ & $\begin{array}{c}-1.7060 * * * \\
(0.2674)\end{array}$ \\
\hline $\operatorname{Roa}_{i, t}$ & $\begin{array}{c}6.5770 * * * \\
(0.4657)\end{array}$ & $\begin{array}{c}5.9284 * * * \\
(0.4624)\end{array}$ & $\begin{array}{c}5.9294 * * * \\
(0.4986)\end{array}$ & $\begin{array}{c}6.5907 * * * \\
(0.4655)\end{array}$ & $\begin{array}{c}6.65533^{* * *} \\
(0.4033)\end{array}$ & $\begin{array}{c}5.6455^{* * *} \\
(0.4510)\end{array}$ & $\begin{array}{c}6.3306^{* * *} \\
(0.4588)\end{array}$ & $\begin{array}{c}6.7180 * * * \\
(0.4025)\end{array}$ \\
\hline $\operatorname{Divs}_{i, t}$ & $\begin{array}{c}0.0659 \\
(0.0705)\end{array}$ & $\begin{array}{c}0.0256 \\
(0.0703)\end{array}$ & $\begin{array}{c}0.0411 \\
(0.0703)\end{array}$ & $\begin{array}{c}0.0729 \\
(0.0700)\end{array}$ & $\begin{array}{c}0.2012^{* *} \\
(0.0989)\end{array}$ & $\begin{array}{c}0.1496 \\
(0.0988)\end{array}$ & $\begin{array}{l}0.1857^{*} \\
(0.0994)\end{array}$ & $\begin{array}{c}0.2418 * * \\
(0.0993)\end{array}$ \\
\hline$R d_{i, t}$ & $\begin{array}{c}1.5415 * * * \\
(0.5105)\end{array}$ & $\begin{array}{c}1.6031^{* * *} \\
(0.5074)\end{array}$ & $\begin{array}{c}1.6540 * * * \\
(0.5175)\end{array}$ & $\begin{array}{c}1.5241 * * * \\
(0.5035)\end{array}$ & $\begin{array}{c}1.5955 * * * \\
(0.2541)\end{array}$ & $\begin{array}{c}1.6727 * * * \\
(0.2530)\end{array}$ & $\begin{array}{c}1.6265^{* * *} \\
(0.2549)\end{array}$ & $\begin{array}{c}1.5428 * * * \\
(0.2538)\end{array}$ \\
\hline$A d v_{i, t}$ & $\begin{array}{c}-1.7315 * * \\
(0.8769)\end{array}$ & $\begin{array}{l}-1.6589 * \\
(0.8793)\end{array}$ & $\begin{array}{l}-1.6151^{*} \\
(0.8994)\end{array}$ & $\begin{array}{c}-1.8024^{* *} \\
(0.8821)\end{array}$ & $\begin{array}{l}-1.8848 \\
(1.4591)\end{array}$ & $\begin{array}{l}-1.8292 \\
(1.4498)\end{array}$ & $\begin{array}{l}-1.8723 \\
(1.4586)\end{array}$ & $\begin{array}{l}-2.0635 \\
(1.4556)\end{array}$ \\
\hline$M b_{i, t}$ & $\begin{array}{c}-1.7315^{* *} \\
(0.8769)\end{array}$ & $\begin{array}{c}0.1630 * * * \\
(0.0359)\end{array}$ & $\begin{array}{c}0.1670 * * * \\
(0.03670)\end{array}$ & $\begin{array}{c}0.1556 * * * \\
(0.0354)\end{array}$ & $\begin{array}{c}0.0925^{* * *} \\
(0.0283)\end{array}$ & $\begin{array}{c}0.1005^{* * *} \\
(0.0282)\end{array}$ & $\begin{array}{c}0.0941^{* * *} \\
(0.0283)\end{array}$ & $\begin{array}{c}0.0932 * * * \\
(0.0282)\end{array}$ \\
\hline $\operatorname{Depr}_{i, t}$ & $\begin{array}{c}0.6035 \\
(1.4899)\end{array}$ & $\begin{array}{c}1.4277 \\
(1.4120)\end{array}$ & $\begin{array}{c}1.7857 \\
(1.4675)\end{array}$ & $\begin{array}{c}0.5543 \\
(1.4915)\end{array}$ & $\begin{array}{c}0.7929 \\
(1.5139)\end{array}$ & $\begin{array}{c}2.0915 \\
(1.5228)\end{array}$ & $\begin{array}{c}1.3218 \\
(1.5548)\end{array}$ & $\begin{array}{c}0.7723 \\
(1.5093)\end{array}$ \\
\hline $\begin{array}{l}\mathrm{N} \\
\mathrm{R}^{2}\end{array}$ & $\begin{array}{l}11,036 \\
0.2611\end{array}$ & $\begin{array}{l}11,036 \\
0.2696\end{array}$ & $\begin{array}{l}11,036 \\
0.2668\end{array}$ & $\begin{array}{l}11,036 \\
0.2624\end{array}$ & $\begin{array}{l}11,036 \\
0.2281\end{array}$ & $\begin{array}{l}11,036 \\
0.2384\end{array}$ & $\begin{array}{l}11,036 \\
0.2291\end{array}$ & $\begin{array}{l}11,036 \\
0.2332\end{array}$ \\
\hline
\end{tabular}

